\title{
Diet of two serrasalmin species, Pygocentrus piraya and Serrasalmus brandtii (Teleostei: Characidae), along a stretch of the rio de Contas, Bahia, Brazil
}

\author{
Márcia Emília de Jesus Trindade ${ }^{1}$ and Ricardo Jucá-Chagas ${ }^{2}$
}

Serrasalmus brandtii and Pygocentrus piraya are two common piranha species in the Barragem da Pedra Reservoir, rio de Contas. In order to identify the diet composition of the two species, monthly collections were performed at three sites between May 2001 and April 2003, using two gill nets of different mesh sizes cast at the beginning of the day and visited after 6, 12 and $24 \mathrm{~h}$. The qualitative composition of the diet was analyzed by determining the frequency of occurrence. Comparison of the two species showed a higher relative abundance of $S$. brandtii (151) compared to P. piraya (55). The food items most frequently found in the stomachs of the two species were fins, fish and shrimp. Serrasalmus brandtii showed a greater feeding plasticity than P. piraya.

Serrasalmus brandtii e Pygocentrus piraya são duas espécies de piranhas comuns no reservatório da Barragem da Pedra, rio de Contas. Com o objetivo de identificar a composição da dieta das duas espécies, foram realizadas coletas mensais em três pontos no período de maio de 2001 a abril de 2003, tendo em cada ponto duas redes de espera com malhas distintas, colocadas no início do dia e visitadas após 6,12 e 24 horas. A composição qualitativa da dieta foi analisada com uso do método de freqüência de ocorrência. A comparação realizada entre as duas espécies descritas revelou haver uma maior abundância relativa de $S$. brandtii (151) em relação à $P$. piraya (55). Os resultados indicaram que os itens: nadadeira, peixes e camarões foram os itens encontrados com maior freqüência nos estômagos de ambas as espécies. Serrasalmus brandtii mostrou uma maior plasticidade alimentar do que a $P$. piraya.

Key words: Neotropical, Feeding, Piranha, Reservoir.

\section{Introduction}

Moyle \& Cech (1988) showed that many fish species are specialists to a greater or lesser extent, but that their true diet at a given time will depend on the availability of typical and atypical food items, as well as on the presence of potentially competing fish species. Thus, the analysis of stomach contents in different seasons of the year and at different sites is necessary to better understand the food spectrum of a species (Gerking, 1994).

The species Serrasalmus brandtii and Pygocentrus piraya are medium-size fish with a strongly compressed and tall body (Britski et al., 1999). Serrasalmus brandtii and P. piraya are carnivorous species with a preferentially ichthyophagous feeding habit and are known as mutilating predators because they remove parts of the body of live prey without killing it. They feed on fins, scales and other parts of the body of their prey, and may also ingest small intact organism when available (Sazima \& Pombal-Jr, 1988; Bistoni \& Haro, 1995).
Among the different exotic fish species found in the Barragem de Pedra Reservoir, the species Serrasalmus brandtii (Lütken, 1875) and Pygocentrus piraya (Cuvier, 1819) were accidentally introduced into the reservoir about 10 years ago due to probable rupture of private tanks in marginal areas during floods.

Agostinho et al. (1994) alerted regarding the ecological damage caused by the effect of introduction of new fish species, which may make management itself unfeasible and exert negative impacts on native species, including the competition for food, space and spawning sites and the introduction of diseases, also permitting the entry of parasites and pathogens in new areas.

The species studied here are particularly important because, in addition to fish hatchery resources, they cause losses to fishermen because of damage to fishing nets and other fish species captured. In addition, the fact that these species are predators suggests their importance for the control of other fish populations of the ecosystem. Furthermore, this is the first study

${ }^{1}$ Programa de Pós-Graduação em Sistemas Aquáticos Tropicais, Universidade Estadual de Santa Cruz, Rodovia Ilhéus-Itabuna km 16, 45662000 Ilhéus, Bahia, Brazil. mejtrindade@hotmail.com

${ }^{2}$ Laboratório de Ecologia, Departamento de Ciências Biológicas, Universidade Estadual do Sudoeste da Bahia, Avenida José Moreira Sobrinho, s/n, 45206-190 Jequié, Bahia, Brazil.rjchagas@uesb.br 
involving feeding aspects of species from the rio de Contas.

In order to provide data regarding trophic interactions, as well as for the management and conservation of the rio de Contas, and particularly of the Barragem de Pedra Reservoir, the present study analyzed the diet of two important serrasalmin species, $S$. brandtii and $P$. piraya.

\section{Material and Methods}

Specimens of the two species were collected monthly between May 2001 and April 2003 along a 4-km stretch of the rio de Contas, which is influenced by the Barragem da Pedra Reservoir, at three sampling sites close to the village of Porto Alegre, municipality of Maracás, Bahia: site 1 (13 $51^{\circ} 19.8^{\prime}$ 'S, $\left.40^{\circ} 37^{\prime} 37.7^{\prime \prime} \mathrm{W}\right)$, located inside the reservoir;

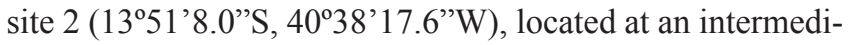
ate position which is less influenced by the reservoir, and site 3 (13 $50^{\prime} 5.7^{\prime}$ 'S , 40 $38^{\prime} 59.3^{\prime \prime} \mathrm{W}$ ), an area which is under the direct influence of the river (Fig. 1).

At each sampling site, two gill nets of different mesh sizes (1.5 and $3.0 \mathrm{~cm}$ between knots) were cast with a motor boat at the beginning of the day and visited after 6,12 and $24 \mathrm{~h}$ for removal and freezing of the captured fish.

In the laboratory, the species were thawed and the following biometric data were determined: total and standard length with an ichthyometer and body weight with a semi-analytical scale. Next, an incision was made in the abdomen, the stomach was removed and its weight was determined with the same balance. The stomachs were fixed in 5\% formaldehyde solution for $48 \mathrm{~h}$ and then stored in $70 \%$ ethanol. Voucher specimens were deposited in the fish collection of the Museu de Zoologia da Universidade de São Paulo (MZUSP), São Paulo, Brazil (MZUSP 75094, 75118, and 75204).

The contents of the stomachs were removed, analyzed under a stereomicroscope and identified to the most specific taxonomic level possible by specialists from the Department of Biological Sciences, UESB, Jequié Câmpus, Bahia, according to specialized literature (Stehr, 1987, 1991). After identification, the parameters frequency of occurrence of the species $(\% \mathrm{~N})$, percent biomass $(\% \mathrm{~W})$, and frequency of occurrence $(\% \mathrm{~F})$ of food items were calculated as follows (Hyslop, 1980):

$$
\% \mathrm{~F}=\frac{\mathrm{n}_{\mathrm{i}}}{\mathrm{n}_{\mathrm{t}}} 100
$$

where $n_{i}$ is the number of individuals of a given item $i$, and $n_{t}$ is the total number of items found in the stomach.

The repletion index (RI), which indicates how full a stomach is, was used to compare repletion between sites and periods studied. The relationship used was adapted from Zavala-Camin (1996), in which content weight was replaced with stomach weight as follows:

$$
\mathrm{RI}=\frac{\mathrm{W}_{\mathrm{s}}}{\mathrm{W}_{\mathrm{f}}} 100
$$

where Ws is stomach weight in grams, and Wf is fish weight in grams.

The t-test was applied to determine significant differences in mean RI between species at the different sites and periods studied using the BioEstat 4.0 program, with the level of significance set at $\alpha=0.05$.
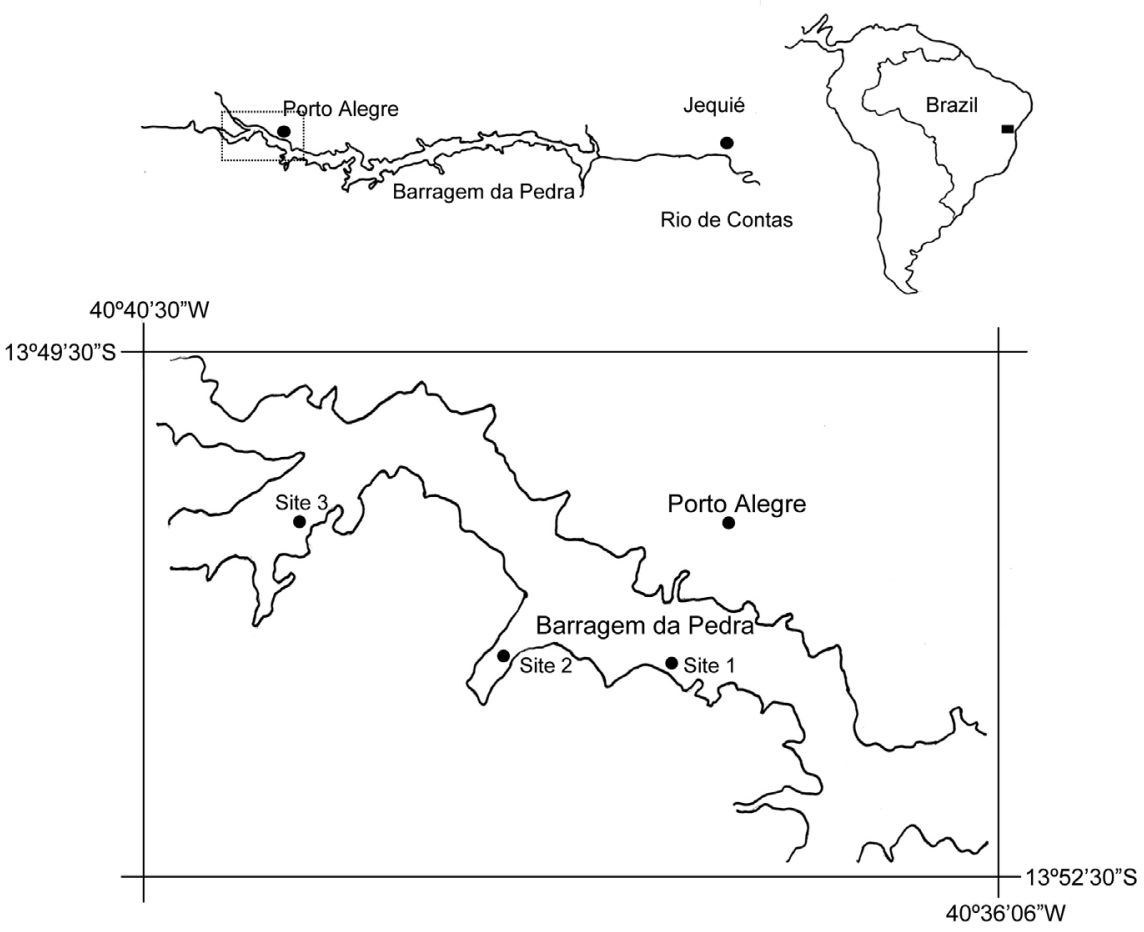

Fig. 1. Location of the sampling sites in the Barragem da Pedra Reservoir, Rio de Contas, Bahia. 
Table 1. Frequency of absolute $(\mathrm{N})$ and percent occurrence $(\% \mathrm{~N})$, absolute $(\mathrm{W})$ and percent biomass $(\% \mathrm{~W})$, and constancy of two serrasalmin species along a stretch of the rio de Contas, Bahia, between May 2001 and April 2003.

\begin{tabular}{lcccccccc}
\hline & \multicolumn{1}{c}{ Species } & & \\
& \multicolumn{1}{c}{ Serrasalmus brandtii } & \multicolumn{7}{c}{ Pygocentrus piraya } \\
\hline Months & $\mathrm{N}$ & $\% \mathrm{~N}$ & $\mathrm{~W}(\mathrm{~g})$ & $\% \mathrm{~W}$ & $\mathrm{~N}$ & $\% \mathrm{~N}$ & $\mathrm{~W}(\mathrm{~g})$ & $\% \mathrm{~W}$ \\
May 2001 & 4 & 2.65 & 128.99 & 1.98 & 1 & 1.82 & 21.83 & 0.63 \\
June 2001 & 10 & 6.62 & 474.03 & 7.29 & 5 & 9.09 & 359.38 & 10.31 \\
July 2001 & 6 & 3.97 & 316.23 & 4.86 & 9 & 16.36 & 705.31 & 20.24 \\
August 2001 & 2 & 1.32 & 74.22 & 1.14 & - & - & - & - \\
September 2001 & 3 & 1.99 & 127.26 & 1.96 & - & - & - & - \\
October 2001 & 2 & 1.32 & 28.81 & 0.44 & - & - & - & - \\
November 2001 & 9 & 5.96 & 348.08 & 5.35 & - & - & - & - \\
December 2001 & 4 & 2.65 & 154.02 & 2.37 & - & - & - & - \\
January 2002 & 3 & 1.99 & 134 & 2.06 & 1 & 1.82 & 64.18 & 1.84 \\
February 2002 & 10 & 6.62 & 538.28 & 8.27 & 2 & 3.64 & 35.47 & 1.02 \\
March 2002 & 15 & 9.93 & 797.85 & 12.26 & 6 & 10.91 & 167.3 & 4.80 \\
April 2002 & 3 & 1.99 & 21.9 & 0.34 & 4 & 7.27 & 195.74 & 5.62 \\
May 2002 & 15 & 9.93 & 625.4 & 9.61 & 17 & 30.91 & 1356.63 & 38.93 \\
June 2002 & 8 & 5.30 & 151.56 & 2.33 & 1 & 1.82 & 51.07 & 1.47 \\
July 2002 & 3 & 1.99 & 241.68 & 3.71 & - & - & - & - \\
August 2002 & 6 & 3.97 & 121.81 & 1.87 & 1 & 1.82 & 82.52 & 2.37 \\
September 2002 & 7 & 4.64 & 580.53 & 8.92 & 2 & 3.64 & 114.84 & 3.30 \\
October 2002 & 8 & 5.30 & 285.38 & 4.39 & - & - & - & - \\
November 2002 & 8 & 5.30 & 290.75 & 4.47 & - & - & - & - \\
December 2002 & 12 & 7.95 & 502.01 & 7.72 & 1 & 1.82 & 134.61 & 3.86 \\
January 2003 & 1 & 0.66 & 3.67 & 0.06 & - & - & - & - \\
February 2003 & 4 & 2.65 & 104.58 & 1.61 & - & - & - & - \\
March 2003 & 3 & 1.99 & 209.62 & 3.22 & 2 & 3.64 & 85.56 & 2.46 \\
April 2003 & 5 & 3.31 & 245.87 & 3.78 & 3 & 5.45 & 110.49 & 3.17 \\
Total & 151 & 100.00 & 6506.53 & 100.00 & 55 & 100.00 & 3484.93 & 100.00 \\
Constancy & & & $100 \%$ & & & $58.3 \%$ & \\
\hline & & & & & & &
\end{tabular}

\section{Results}

A total of 206 individuals were recorded during the period between May 2001 and April 2003, including 151 S. brandtii and 55 P. piraya specimens.

The highest percent biomass was observed in March 2002 for $S$. brandtii (W\% = 12.26) and in May 2002 for P. piraya $(\mathrm{W} \%=38.93)($ Table 1). Regarding constancy, S. brandtii occurred throughout the sampling period $(\mathrm{C}=100 \%)$, whereas P. piraya was only found during 14 months of collection (C $=58.3 \%)$ (Table 1). The absence of this species might be related to the dry period during which the water level was markedly reduced.

Comparison of the frequencies of occurrence of food items (\%) determined by the analysis of stomach content revealed fish (Teleostei), scales and shrimp (Macrobrachium amazonicum) as the most frequent items in $S$. brandtii and scales, fish (Teleostei) and shrimp (M. amazonicum) as the most frequent items in P. piraya (Fig. 2).

Analysis of the three sampling sites revealed scales, fish (Teleostei) and shrimp (M. amazonicum) as the predominant food items in the stomach of the two species. Fish fins and plant matter were also detected at a lower frequency at all sampling sites (Fig. 3).

Comparison of the frequency of occurrence (\%) of different food items between the two species at the different sampling sites showed the presence, although at a discrete percentage, of some different invertebrates in the stomach of $S$. brandtii, and the presence of Odonata, Oligochaeta and Nematoda in P. piraya (Fig. 3).



Fig. 2. Total frequency of occurrence (\%) of different food items determined by the analysis of the stomach content of Serrasalmus brandtii and Pygocentrus piraya collected between May 2001 and April 2003 according to the three sampling sites. 
Table 2. Mean repletion index obtained for the two serrasalmin species of the rio de Contas, Bahia, collected during different periods of the day between May 2001 and April 2002. Values are the mean \pm standard deviation.

\begin{tabular}{lcc}
\hline Species (N) & Repletion index & Period \\
\hline Sbra (19) & $4.47 \pm 1.92$ & Morning \\
Ppir (10) & $5.61 \pm 2.54$ & \\
Sbra (15) & $4.44 \pm 1.56$ & Afternoon \\
Ppir (5) & $5.55 \pm 2.23$ & \\
Sbra (34) & $4.26 \pm 1.97$ & Night \\
Ppir (13) & $6.82 \pm 3.37$ & \\
\hline
\end{tabular}

In $S$. brandtii, the values of the most important food items (fish, shrimp, scales and fins) were higher during the afternoon period. In P. piraya, scales, fish, unidentified material and plant matter were also more frequent in the afternoon. A higher percentage of shrimp was observed during the night (Fig. 4).

Comparison of the mean RI using the t-test for different periods (morning, afternoon and night) and sampling sites (sites 1,2 and 3) showed no significant difference between the two species ( $p=0.96$ and $p=0.12$, respectively) (Tables 2 and 3 ).

\section{Discussion}

Recent studies have demonstrated a wide variety of feeding habits for different piranha species (Goulding et al., 1988; Sazima \& Machado, 1990). Luiz et al. (1998) observed that Serrasalmus marginatus mainly feeds on fish, followed by plant matter, and classified this species as fish-eating. Analyzing the stomach content of another species of the same gender,
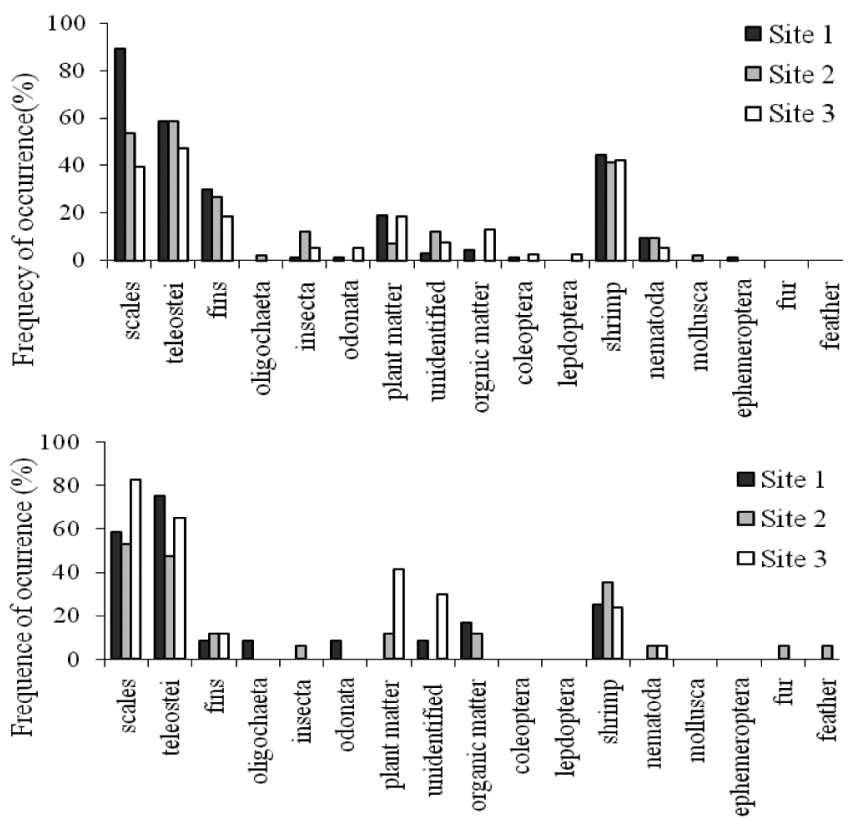

Fig. 3. Frequency of occurrence (\%) of different food items determined by the analysis of the stomach content of Serrasalmus brandtii (a) and Pygocentrus piraya (b) collected between May 2001 and April 2003 according to the three sampling sites.
Table 3. Mean repletion index obtained for the two serrasalmin species of the rio de Contas, Bahia, collected at different sampling sites between May 2001 and April 2002. Values are the mean \pm standard deviation.

\begin{tabular}{lcc}
\hline Species (N) & Repletion index & Site \\
\hline Sbra (39) & $3.98 \pm 1.44$ & Site 1 \\
Ppir (10) & $5.66 \pm 3.28$ & \\
Sbra (16) & $3.90 \pm 1.42$ & Site 2 \\
Ppir (11) & $6.61 \pm 2.65$ & \\
Sbra (13) & $6.07 \pm 6.48$ & Site 3 \\
Ppir (7) & $6.17 \pm 2.96$ & \\
\hline
\end{tabular}

S. altuvei, Leão et al. (1991) identified intact fish, plant matter, scales, adult insects, eggs and insect larvae, and classified this species as omnivorous with a trend towards fish-eating.

In the present study, S. brandtii showed a greater feeding plasticity than P. piraya, with even the presence of Ephemeroptera, Odonata, Coleoptera, Mollusca and other invertebrates being observed in some stomachs analyzed. In contrast, the same plasticity was not observed for $P$. piraya which, therefore, cannot be considered a generalist such as $P$. nattereri (Piorski et al., 2005). Recently, Resende (2000), studying the trophic structure of fish in Baixo Miranda, Pantanal of Mato Grosso, included two species of the genus Serrasalmus and one species of the genus Pygocentrus in an ichthyophagous trophic guild. In the present study, we also observed the presence of fish scales and fins in the stomachs analyzed. Sazima \& Machado (1990), investigating the feeding behavior of two species of the genus Serrasalmus and of one species of the genus Pygocentrus in the Pantanal region, Mato Grosso, Brazil, observed a high frequency of these items: fins $(84.6 \%)$ and
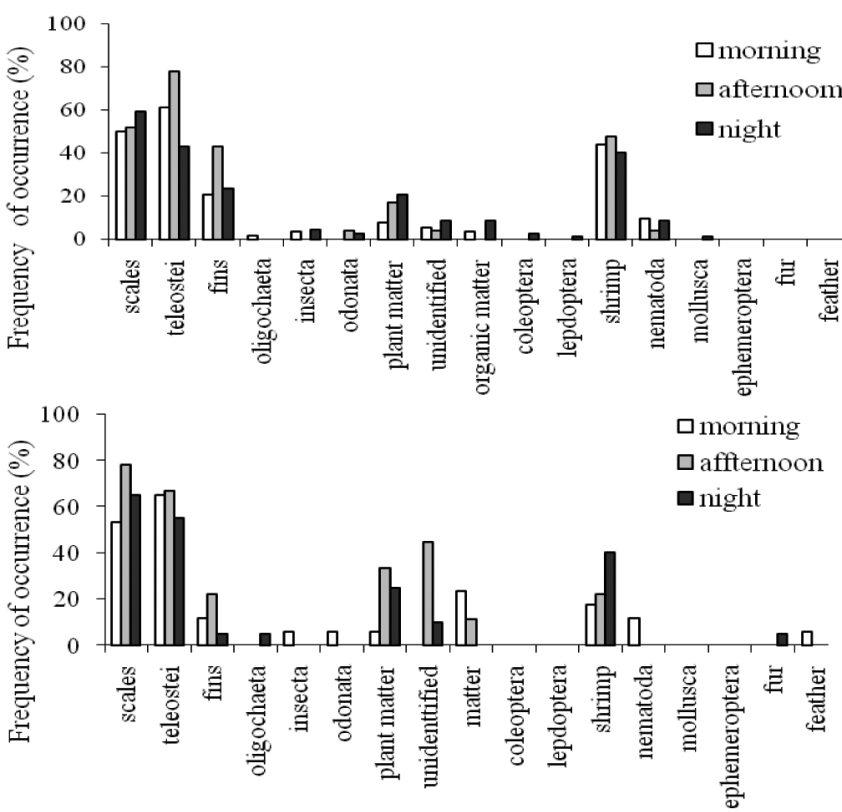

Fig. 4. Frequency of occurrence (\%) of different food items determined by the analysis of the stomach content of Serrasalmus brandtii (a) and Pygocentrus piraya (b) collected between May 2001 and April 2003 according to the three daily sampling periods. 
scales $(76.9 \%)$. However, in the present study the frequency of occurrence of fish fins was not higher when compared to the other items found in the stomachs of $S$. brandtii and P. piraya.

According to Gerking (1994), the behavior of feeding on fish fins has been observed since the 1960s in families of both marine and freshwater fish such as Cichlidae, Tetraodontidae, Citharinidae, Blennidae, Belontiidae, and Characidae. Some species such as citharinids may exclusively feed on fins as reported by Matthes (1961), but other types of food have been identified in the digestive tract of many other species.

Leão et al. (1991), studying a rare piranha species of the genus Serrasalmus in the lower rio Negro, showed that, although Serrasalminae species share a common type of dentition adapted to their unusual habit of cutting and tearing apart pieces of fish, this is not the only or even the main feeding habit of some species. Fish scales and fins represent the main dietary item of S. elongatus. These findings do not agree with the present results, which showed a higher frequency of fish, scales and shrimp in the stomach of $S$. brandtii, whereas in P. piraya scales, fish and shrimp were found.

Bistoni \& Haro (1995), studying the feeding habit of a species of the genus Serrasalmus in marshes formed by the Dulce River in the northeast region of the Province of Cordoba, observed that regardless of their size piranhas consume diverse fish species throughout their life cycle, ingesting the whole prey or pieces of the body. This was also observed in the present study.

However, it should be emphasized that Astronotus ocellatus, which was also introduced in the Barragem da Pedra Reservoir, is generally found to be in a perfect state when captured, presenting no damage caused by predators. According to the literature, this South American cyclid contains caudal ocelli that reduce predation of their fins by piranhas of the genus Serrasalmus. Winemiller (1990) explained that these eyespots apparently confuse visual recognition between the caudal region of the prey and its head and this confusion reduces the attack by piranhas.

Another interesting factor is the seasonality of tropical ecosystems. According to Lowe-McConnell (1999), water level variation is mainly caused by seasonal changes in the habitat which may influence the availability of food resources and, consequently, the qualitative and quantitative occurrence of fish. These findings may explain the disappearance of $P$. piraya during the period between August and December 2001, when the water level was very low and less food was probably available.

In a study on the ecological aspects of the ichthyofauna community in the Barra Bonita Reservoir, São Paulo, Castro (1997) observed that S. spilopleura was constantly found at the three sampling sites throughout the period of monthly collections and suggested that the influence of seasonal migrations on this species is small. The same was observed for $S$. brandtii which was constantly present during both the rainy and dry periods when collections were performed.

Although constancy is a qualitative measure, it may also be an indicator of residency. Uieda (1984) stated that the study of constancy of species in a given community may demonstrate not only migrating or occurring species, but also a possible effect of seasonal alterations on the community.

Lowe-McConnell (1999) reported that due to seasonal instabilities and changes in their biotopes highly specialized trophic groups are absent in tropical water bodies. Thus, although most tropical species belong to the group of eurytrophic species, it is possible to classify fish species into more or less specific categories according to the predominant food. In the present study, analysis of the stomach contents of the two species indicated a higher frequency of scales, fish and shrimp, a finding that characterizes these species as carnivores.

The low proportion of invertebrates and plant matter observed might be the result of the feeding specialization itself of piranhas. Similar findings have been reported by MachadoAllison \& Garcia (1986) who studied three piranha species in Venezuela. The authors observed that insects and other invertebrates are not important items of the diet of these fish.

The gastric RI has been shown to be useful as an approximation regarding the feeding intensity of a given species, with this index being necessary to recognize the feeding rhythm of a species (Zavala-Camin, 1996). The present study showed homogenous repletion in both species, indicating regularity in feeding for piranhas in the reservoir studied, with no period of the day or site showing a more intense activity.

With respect to standard and total length, the structures of the species were found to be in a perfect state, presenting no damage caused by some predator. In this case, these results may indicate that even when captured by nets piranhas do not predate on each other. The same is not observed for other captured species. Predation of piranhas of the genus Serrasalmus on other fish species has been reported by Lowe-McConnell (1999) in Guiana. The same was also demonstrated by Teles \& Godinho (1997) in fishing experiments carried out in the Três Marias Dam, Rio São Francisco, using gill nets of mesh sizes of 8,10 and $12 \mathrm{~cm}$. In that study, S. brandtii was found to affect the quantity of fish caught in that environment since it attacks the fish captured in the nets, in addition to damaging the fishing equipment.

Within this context, Agostinho et al. (1994) suggested that the conservation of the area between the Itaipu Reservoir and the flood plain of the rio Paraná should be extended to other reservoirs. These recommendations include limiting human occupation of the area, a better control of the transport of live fish, the requirement for documents specifying fishing methods, compatibility of the operational procedures used by upstream barriers in order to minimize flow according to the requirements for migrating species, particularly during the reproductive period, and reevaluation of the cost/benefit ratio for future hydroelectric power plants in terms of the loss of biological diversity and of the quantity of fish caught.

\section{Acknowledgements}

We thank UESB and FINEP for financial support. CNPq provided fellowship for author. We are thankfull to students 
and colleagues at the ECOFAU workgroup and Associação de Trabalhadores Rurais e Pescadores de Porto Alegre, Maracás, Bahia for support in field work

\section{Literature Cited}

Agostinho, A. A., H. F. Julio Jr. \& M. Petrere Jr. 1994. Itaipu reservoir (Brazil): impacts of the impoundment of the fish fauna and fisheries. Pp.171-184. In: Cox, I.G. (Ed.). Rehabilitation of freshwater fisheries. Oxford, Fishing News Books, 260p.

Bistoni, M. L. A. \& J. G. Haro. 1995. Hábitos alimentares de Serrasalmus spilopleura (Pisces, Serrasalmidae) En Los Banâdos Del Río Dulce (Córdoba, Argentina). Revista Brasileira de Biologia, 55(4): 847-853.

Britski, H. A., K. Z. S. Silimon \& B. S. Lopes. 1999. Peixes do Pantanal: manual de identificação. Embrapa, Brasília, 184p.

Castro, A. C. L. 1997. Aspectos ecológicos da comunidade ictiofaunística do reservatório de Barra Bonita, SP. Revista Brasileira de Biologia, 57(4): 665-676.

Gerking, S. D. 1994. Feeding ecology of fish. San Diego. Academic Press, $415 p$.

Goulding, M., M. L. Carvalho \& E. J. G. Ferreira. 1988. Rio Negro: rich life in poor water. Hague, The Netherlands, SPB, Academic Publishing, 200p.

Hyslop, E. J. 1980. Stomach content analysis - a review of methods and their application. Journal of Fish Biology, 17: 411-429.

Leão, E. L. M., P. T. C. Chaves, R. G. Leite \& E. Ferraz. 1991. Aspectos da reprodução, alimentação e parasitofauna de uma espécie rara de piranha, Serrasalmus altuvei (Ramírez, 1965) (Pisces, Serrasalmidae) do baixo rio Negro. Revista Brasileira de Biologia, 51(3): 545-553.

Lowe-McConnell, R. H. 1999. Estudos ecológicos de comunidades de peixes tropicais. São Paulo, EDUSP, 534p.

Luiz, E. A., A. A. Agostinho, L. C. Gomes \& N. S. Hanh. 1998. Ecologia trófica de peixes em dois riachos da bacia do Rio Paraná. Revista Brasileira da Biologia, 58: 273-285.
Machado-Allison, A. \& C. Garcia 1986. Food habits and morphological changes during ontogeny in three Serrasalmin species of the Venezuelan floodplains. Copeia, 1986(1): 193-196.

Matthes, H. 1961. Feeding habit of some Central African freshwater fishes. Nature (London), (192): 78-80.

Moyle, P. B. \& J. J. Cech, Jr. 1988. Fishes: an introduction to ichthyology. 2 Ed. New Jersey, Englewood Cliffs, Prentice Hall, 559p.

Piorski, N. M., J. R., Alves, M. R. D. Machado \& M. M. V. Correia. 2005. Alimentação e ecomorfologia de duas espécies de piranhas (Characiformes: Characidae) do lago de Viana, estado do Maranhão, Brasil. Acta Amazônica, 35(1): 63-70.

Resende, E. K. 2000. Trophic structure of fish assemblages in the lower Miranda river, Pantanal, Mato Grosso do Sul State, Brazil Revista Brasileira de Biologia, 60(3): 389-403.

Sazima, I. \& F. A. Machado. 1990. Underwater observations of piranhas in western Brazil. Environmental Biology of Fishes, 28: $17-31$

Sazima, I. \& J. P. Pombal, Jr. 1988. Mutilação de nadadeiras em acarás, Geophagus brasiliensis, por piranhas, Serrasalmus spilopleura. Revista Brasileira de Biologia, 48(3): 477-483.

Stehr, F. W. 1987. Immature Insects. Dubuque, Iowa, Kendall/Hunt Publishing Company, 754p.

Stehr, F. W. 1991. Immature Insects. Dubuque, Iowa, Kendall/Hunt Publishing Company, 974p.

Teles, M. E. O. \& H. P. Godinho. 1997. Ciclo reprodutivo da pirambeba Serrasalmus brandtii (Teleostei, Characidae) na represa de Três Marias, rio São Francisco. Revista Brasileira de Biologia, 57(2): 177-184.

Uieda, V. S. 1984. Ocorrência e distribuição dos peixes em um riacho de água doce. Revista Brasileira de Biologia, 44(2): 203-213.

Winemiller, K. O. W. 1990. Caudal eyespots as deterrents against fin predation in the Neotropical Cichlid Astronotus ocellatus. Copeia, 1990(3): 665-673.

Zavala-Camin, L. A. 1996. Introdução aos estudos sobre alimentação natural em peixes. Maringá, EDUEM, 129p.

Accepted October 2008

Published December 22, 2008 